\title{
Solid-State Dye-Sensitized Solar Cells Using Red and Near-IR Absorbing Bodipy Sensitizers
}

2010

Vol. 12, No. 17

$3812-3815$

\section{Safacan Kolemen, ${ }^{\dagger}$ Yusuf Cakmak, $^{\ddagger}$ Sule Erten-Ela, ${ }^{\S}, \|$ Yigit Altay, ${ }^{\dagger}$ Johannes Brendel," Mukundan Thelakkat," and Engin U. Akkaya*,t,‡}

Department of Chemistry, Bilkent University, Ankara 06800, Turkey, UNAM-Institute of Materials Science and Nanotechnology, Bilkent University, Ankara 06800, Turkey, Institute of Solar Energy, Ege University, Bornova, Izmir 35100, Turkey, and Macromolecular Chemistry I, Applied Functional Polymers, University of Bayreuth, 95440 Bayreuth, Germany

eua@fen.bilkent.edu.tr

Received June 27, 2010

\section{ABSTRACT}

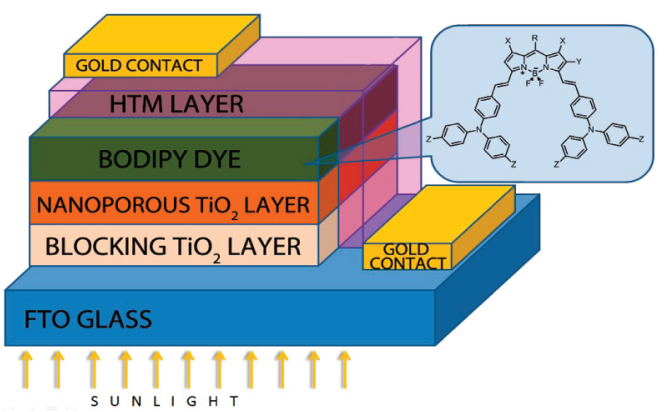

Boron-dipyrrin dyes, through rational design, yield promising new materials. With strong electron-donor functionalities and anchoring groups for attachment to nanocrystalline $\mathrm{TiO}_{2}$, these dyes proved useful as sensitizers in dye-sensitized solar cells. Their applicability in a solid-state electrolyte regime offers additional opportunities for practical applications.

Dye-sensitized solar cells (DSSC) are successful alternatives to more widely used traditional semiconductor-based designs. The DSSC technology is being vigorously developed through commercial enterprises. ${ }^{1}$ In fact, in the European Union Photovoltaic Roadmap, it was suggested that by the year 2020, DSSCs are expected to be a significant contributor to

\footnotetext{
Department of Chemistry, Bilkent University.

UNAM-Institute of Materials Science and Nanotechnology, Bilkent University.

${ }^{\S}$ Ege University.

"University of Bayreuth.

(1) (a) O'Regan, B.; Grätzel, M. Nature 1991, 353, 737. (b) Grätzel, M. Nature 2001, 414, 338. (c) Eisenberg, R.; Nocera, D. G. Inorg. Chem. 2005, 44, 6799. (d) Armaroli, N.; Balzani, V. Angew. Chem. 2007, 119 52; Angew. Chem., Int. Ed. 2007,, 46, 52. (e) Robertson, N. Angew. Chem., Int. Ed. 2008, 47, 1012. (f) Lewis, N.; Nocera, D. Proc. Natl. Acad. Sci. U.S.A. 2006, 103, 15729. (g) Nazeeruddin, M. K. Coord. Chem. Rev. 2004, 248,1161
}

renewable electricity generation. ${ }^{2}$ However, most people would agree that there is still room for improvement for a few components of a typical DSSC. ${ }^{3}$ This is perhaps more apparent for the electrolyte and the sensitizer dye component itself. For use as redox mediator, $\mathrm{I}^{-}$and $\mathrm{I}_{2}$ (to generate iodide/ triiodide redox couple) is typically dissolved in organic solvents (such as acetonitrile). However, the use of solvents creates temperature stability problems, and because of the volatility of the solvents, sealing of the cell is crucial. Most plastics are not compatible with organic solvents, and thus the use of liquid electrolytes effectively preclude integration

(2) Jager-Waldau, A. Renewable Sustainable Energy Rev. 2007, 11, 1414

(3) Yum, J. H.; Chen, P.; Grätzel, M.; Nazeeruddin, M. K. ChemSusChem 2009, 1, 699. 
into flexible structures. Also, ruthenium dyes are expensive, and their preparation includes lengthy purification steps. ${ }^{4}$ Accurate engineering of the sensitization wavelength would also benefit from a replacement organic dye. Not surprisingly, a large number of laboratories around the world are actively pursuing potential candidates for sensitizers for DSSC applications. ${ }^{5}$

Boron-dipyrrin or Bodipy dyes are interesting chromophores with high quantum yields and absorptivity, ${ }^{6}$ typically with typical bright green fluorescence. $\mathrm{We}^{7}$ and others ${ }^{8}$ have found ways to transform these dyes to absorb essentially all colors of the rainbow and then some. A few years ago, we published the first report ${ }^{9}$ of a rationally functionalized Bodipy-based photosensitizer, taking advantage of some of the superior characteristics of this class of dyes. Others followed with equally promising Bodipy derivatives. ${ }^{10}$ Calculations at various levels of the theory ${ }^{9,11}$ suggested that excitation of the Bodipy chromophore results in significant reorganization of the electron distribution,

(4) Choi, H.; Raabe, I.; Kim, D.; Teocoli, F.; Kim, C.; Song, K.; Yum, J.-H.; Ko, J.; Nazeeruddin, M. K.; Grätzel, M. Chem.-Eur. J. 2010, 16, 1193.

(5) (a) Mishra, A.; Fischer, M. K. R.; Bauerle, P. Angew. Chem., Int. Ed. 2009, 48, 2474. (b) Ooyama, Y.; Harima, Y. Eur. J. Org. Chem. 2009 2903. (c) Hagberg, D. P.; Yum, J.-H.; Lee, H.; De Angelis, F.; Marinado, T.; Karlsson, K. M.; Humphry-Baker, R.; Sun, L.; Hagfeldt, A.; GlAdratzel, M.; Nazeeruddin, M. K. J. Am. Chem. Soc. 2008, 130, 6259. (d) Ito, S.; Zakeeruddin, S. M.; Humphry-Baker, R.; Liska, P.; Charvet, R.; Comte, P.; Nazeeruddin, M. K.; Péchy, P.; Takata, M.; Miura, H.; Uchida, S. Grätzel, M. Adv. Mater. 2006, 18, 1202. (e) Hwang, S.; Lee, J. H.; Park, C.; Lee, H.; Kim, C.; Park, C.; Lee, M.-H.; Lee, W.; Park, J.; Kim, K.; Park, N.-G.; Kim, C. Chem. Commund. 2007, 4887. (f) Ito, S.; Miura, H.; Uchida, S.; Takata, M.; Sumioka, K.; Liska, P.; Comte, P.; Péchy, P.; Grätzel, M. Chem. Commun. 2008, 5194. (g) He, J.; Benkö, G.; Korodi, F.; Polivka, T.; Lomoth, R.; Åkermark, B.; Sun, L.; Hagfeldt, A.; Sundström, V. J. Am. Chem. Soc. 2002, 124, 4922. (h) Velusamy, M.; Huang, J.-H.; Hsu, Y.-C.; Chou, H.-H.; Ho, K.-C.; Wu, P.-L.; Chang, W.-H.; Lin, J. T.; Chu, C. W. Org. Lett. 2009, 11, 4898. (i) Mei, J.; Graham, K. R.; Stalder, R.; Reynolds, J. R. Org. Lett. 2010, 12, 660. (j) Koumura, N.; Wang, Z. S.; Mori, S.; Miyashita, M.; Suzuki, E.; Hara, K. J. Am. Chem. Soc. 2006, 128, 14256. (k) Lin, J. T.; Chen, P.-C.; Yen, Y.-S.; Hsu, Y.-C.; Chou, H.H.; Yeh, M.-C. P. Org. Lett. 2009, 11, 97. (1) Lohwasser, R. H.; Bandara, J.; Thelakkat, M. J. Mater. Chem. 2009, 19, 4126.

(6) Recent reviews on BODIPY dyes, see: (a) Ulrich, G.; Ziessel, R.; Harriman, A. Angew. Chem., Int. Ed. 2008, 47, 1184. (b) Ziessel, R.; Ulrich, G.; Harriman, A. New J. Chem. 2007, 31, 496. (c) Loudet, A.; Burgess, K. Chem. Rev. 2007, 107, 4891.

(7) (a) Buyukcakir, O.; Bozdemir, O. A.; Kolemen, S.; Erbas, S.; Akkaya, E. U. Org. Lett. 2009, 11, 4644. (b) Cakmak, Y.; Akkaya, E. U. Org. Lett. 2009, 11, 85. (c) Erbas, S.; Gorgulu, A.; Kocakusakogullari, M.; Akkaya, E. U. Chem. Commun. 2009, 33, 4956. (d) Dost, Z.; Atilgan, S.; Akkaya, E. U. Tetrahedron 2006, 62, 8484. (e) Deniz, E.; Isbasar, G. C.; Bozdemir, O. A.; Yildirim, L. T.; Siemiarczuk, A.; Akkaya, E. U. Org. Lett. 2008, 10,3401 .

(8) (a) Rurack, K.; Kollmannsberger, M.; Daub, J. Angew. Chem., Int. Ed. 2001, 40, 385. (b) Umezawa, K.; Nakamura, Y.; Makino, H.; Citterio, D.; Suzuki, K. J. Am. Chem. Soc. 2008, 130, 1550. (c) Zhang, D.; Wen, Y.; Xiao, Y.; Yu, G.; Liu, Y.; Qian, X. Chem. Commun. 2008, 4777. (d) Atilgan, S.; Kutuk, I.; Ozdemir, T. Tetrahedron Lett. 2010, 51, 892.

(9) Erten-Ela, S.; Yilmaz, D.; Icli, B.; Dede, Y.; Icli, S.; Akkaya, E. U. Org. Lett. 2008, 10, 3299.

(10) (a) Rousseau, T.; Cravino, A.; Bura, T.; Ulrich, G.; Ziessel, R.; Roncali, J. Chem. Commun. 2009, 1673. (b) Rousseau, T.; Cravino, A.; Bura, T.; Ulrich, G.; Ziessel, R. J. Mater. Chem. 2009, 19, 2298. (c) Hattori, S.; Ohkubo, K.; Urano, Y.; Sunahara, H.; Nagano, T.; Wada, Y.; Tkachenko, N. V.; Lemmetyinen, H.; Fukuzumi, S. J. Phys. Chem. B 2005, 109, 15368. (d) Forgie, J. C.; Skabara, P. J.; Stibor, I.; Vilela, F.; Vobecka, Z. Chem. Mater. 2009, 21, 1784. (e) Lee, C. Y.; Hupp, J. T. Langmuir 2010, 26, 3760. (f) Kumaresan, D.; Thummel, R. P.; Bura, T.; Ulrich, G.; Ziessel, R. Chem.-Eur. J. 2009, 15, 6335.

(11) Bozdemir, O. A.; Guliyev, R.; Buyukcakir, O.; Selcuk, S.; Kolemen, S.; Gulseren, G.; Nalbantoglu, T.; Boyaci, H.; Akkaya, E. U. J. Am. Chem. Soc. 2010, 132, 8029 . setting up the scene for efficient electron transfer to nanocrystalline titania from the $S_{1}$ state of the dye. Needless to say, further optimization of the Bodipy derivatives may provide better sensitizers for use in DSSCs.

In order to bypass the limitations imposed by liquid electrolytes, one of the most common hole transport materials (HTM) is 2,2',7,7'-tetrakis( $N, N$-di- $p$-methoxyphenyl-amine)$9,9^{\prime}$-spirobifluorene (spiro-OMeTAD). ${ }^{51,12}$ In this work, our goal was to investigate the performance of rationally designed boron-dipyrrin sensitizers in connection with spiro-OMeTAD hole transport material.

In our previous work, ${ }^{9}$ we synthesized sensitizer 1 (Figure 1) and reported its efficiency in a standard DSSC setup using

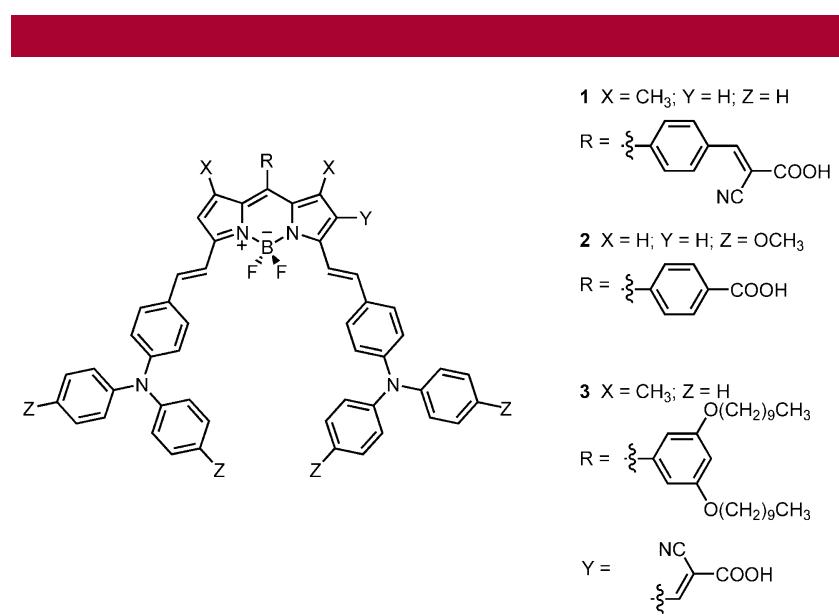

Figure 1. Sensitizers used in this study.

a iodide/triiodide redox couple in solution as electrolyte. In this work, however, we targeted two more boron-dipyrrin dyes, compounds $\mathbf{2}$ and $\mathbf{3}$, in an attempt to clarify relative effects of various modifications on the efficiency. The rationale behind the two new sensitizers was as follows. In compound $\mathbf{1}$, the meso-phenyl substituent is orthogonal as a result of the presence of methyl groups at the 3 and 5 positions of the Bodipy core. It is very likely that a new sensitizer in which protruding methyls are not present (such as sensitizer 2) could have the phenyl substituent with a smaller dihedral angle, leading to extended conjugation and facilitated charge transfer from the donor groups to the electron-withdrawing (and anchoring) carboxylic acid terminal. In addition, in sensitizer $\mathbf{2}$, we placed additional electron-donor $p$-methoxy groups on the diphenylaminophenyl charge donor moiety, again looking for a more efficient excited state charge transfer. In the design of sensitizer $\mathbf{3}$, we included two decyl chains on the meso-phenyl substituent in order to minimize aggregation-induced losses in efficiency. In addition, a cyanoacetic acid derived electron-withdrawing anchor group was moved to position 2 of the Bodipy core. It is apparent that in this design the cyano acetylidene group will be in full conjugation with the Bodipy chromophore.

The syntheses of the novel sensitizers $\mathbf{2}$ and $\mathbf{3}$ were based on versatile Bodipy chemistry. 8-Carboxyphenyl-Bodipy (4)

(12) (a) Bach, U.; Lupo, D.; Comte, P.; Moser, J. E.; Weissörtel, F.; Salbeck, H.; Spreitzer, H.; Grätzel, M. Nature 1998, 395, 583. 
was synthesized from appropriate precursors, and then double Knoevenagel condensation reactions with the appropriate diphenylaminophenylbenzaldehyde compound resulted in the sensitizer $\mathbf{2}$, following rather routine purification procedures. In the synthesis of sensitizer 3, we first prepared 3,5didecyloxyphenyl-substituted Bodipy $\mathbf{5}^{7 \mathrm{~b}}$ Formylation following the procedure in a recent report $^{13}$ resulted in compound 6. Cyanoacetic acid reacts with the formyl-bodipy 6 in toluene, resulting in compound 7. In the final step, a double Knoevenagel condensation with the appropriate aldehyde yields the target sensitizer $\mathbf{3}$. All new compounds were analytically pure (Supporting Information).

First the absorbance spectra in solution $\left(\mathrm{CHCl}_{3}\right)$ (Figure 2) and as adsorbed on $\mathrm{TiO}_{2}$ (Figure 3) were obtained. The
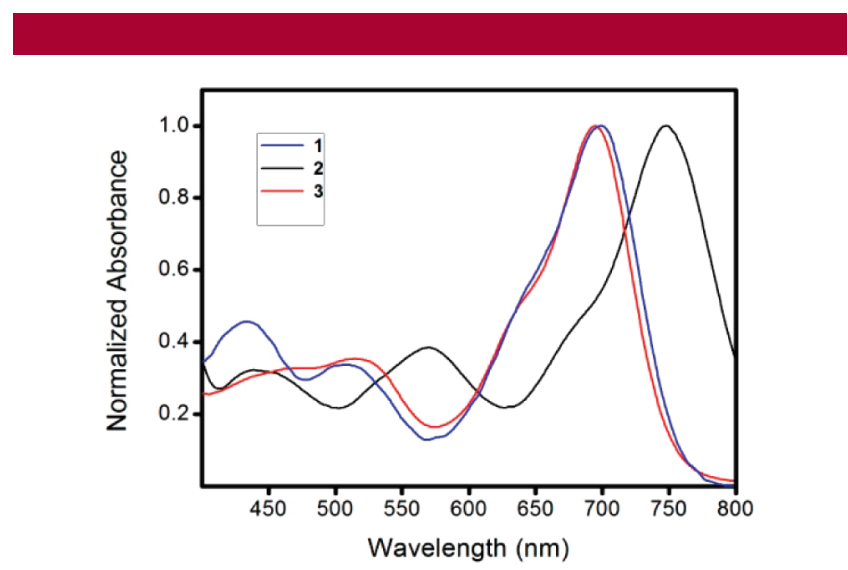

Figure 2. Normalized absorption spectra of the sensitizers in $\mathrm{CHCl}_{3}$.

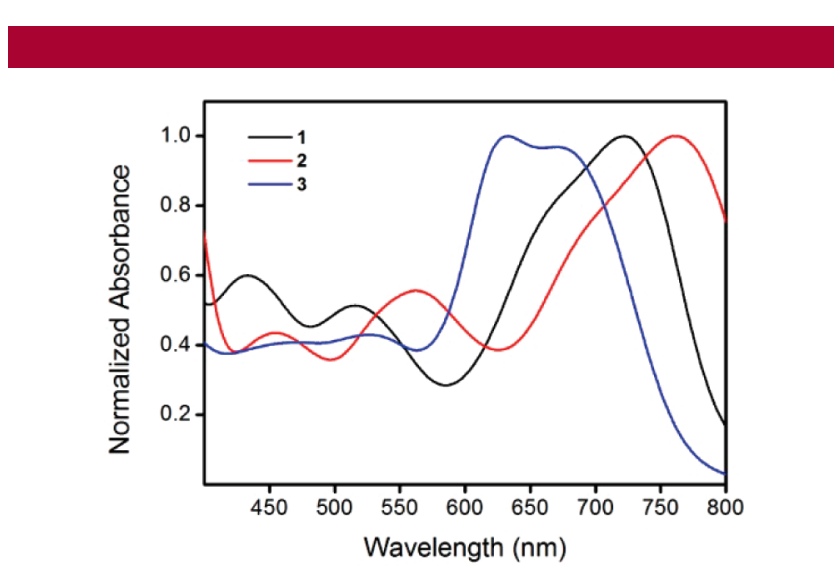

Figure 3. Normalized absorption spectra of the sensitizers adsorbed on nanocrystalline $\mathrm{TiO}_{2}$.

chromophores in solution have strong absorption peaks in the red and near-IR regions of the visible spectrum. As expected, on absorption over titania, peaks are significantly broadened, suggesting aggregation of the sensitizers in the adsorbed film.

The sensitizers $\mathbf{1}-\mathbf{3}$ were further characterized by cyclic voltammetry and absorption spectroscopy in solution

(13) Jiao, L.; Yu, C.; Li, J.; Wang, Z.; Wu, M.; Hao, E. J. Org. Chem. 2009, 74, 7525 .
(Table 1). It is clear that the LUMO energies of the sensitizers are appropriate for efficient electron injection to $\mathrm{TiO}_{2}$.

Table 1. Optical and Electrochemical Properties of Sensitizers 1-3

\begin{tabular}{lcccccc}
\hline dye & $\begin{array}{c}\lambda_{\max }(\mathrm{abs})^{a} \\
(\mathrm{~nm})\end{array}$ & $\begin{array}{c}E_{\max }{ }^{a} \\
(\mathrm{mV})\end{array}$ & $\begin{array}{c}E_{\mathrm{red}}{ }^{b} \\
(\mathrm{mV})\end{array}$ & $\begin{array}{c}\mathrm{HOMO}^{b} \\
(\mathrm{eV})\end{array}$ & $\begin{array}{c}\mathrm{LUMO}^{b} \\
(\mathrm{eV})\end{array}$ \\
\hline $\mathbf{1}$ & 699 & 69500 & 680 & -890 & -5.09 & -3.52 \\
$\mathbf{2}$ & 746 & 66000 & 560 & -870 & -5.05 & -3.62 \\
$\mathbf{3}$ & 695 & 79000 & 720 & -940 & -5.21 & -3.55 \\
${ }^{a}$ Absorption data were collected in $\mathrm{CHCl}_{3 .}{ }^{b}$ Electrochemical data were \\
collected in $\mathrm{CH}_{2} \mathrm{Cl}_{2}$. Potentials are quoted with reference to the internal \\
ferrocene standard.
\end{tabular}

The solid-state cells were prepared as in the previous reports. For a brief procedure, please see Supporting Information. Incident photon to current conversion plots were obtained under standard conditions (AM 1.5G, $100 \mathrm{~mW}$ $\mathrm{cm}^{-2}$ ). The results show that the sensitizer 1 has the highest efficiency (Figure 4). Only beyond $800 \mathrm{~nm}$, sensitizer 2 has

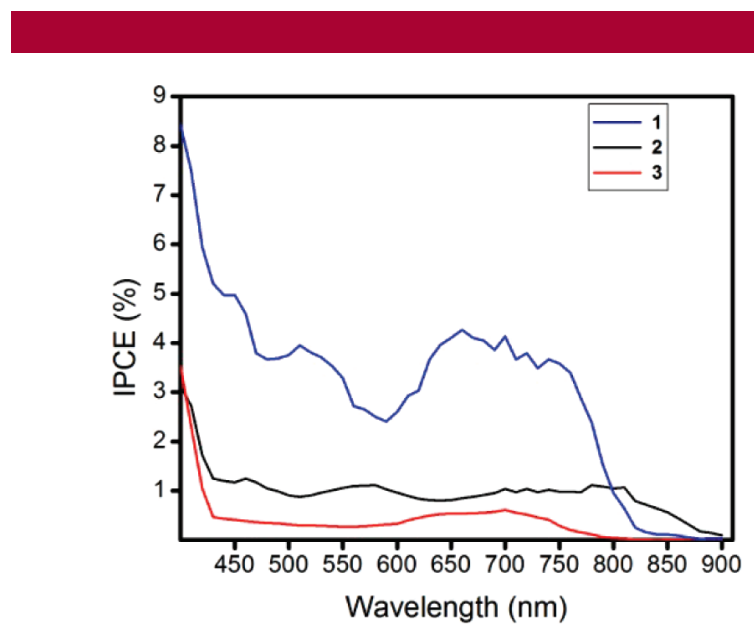

Figure 4. Incident photon to current conversion efficiency as a function of wavelength for the solid-state DSSCs prepared as described in Supporting Information.

IPCE values higher than those of $\mathbf{1}$. For sensitizer 3, IPCE values are below $1 \%$ in the $450-850 \mathrm{~nm}$ region. The data can be interpreted as follows. As we suggested previously, the meso position ( 8 position) is particularly important. In the parent Bodipy and in other derivatives, theoretical calculations suggest that on excitation there is significant charge relocalization on the meso carbon. ${ }^{9}$ Sensitizers $\mathbf{1}$ and 2 take advantage of this natural Bodipy tendency for charge relocalization onto meso-carbon, by placing electron-acceptor/anchor groups on that position. The sensitizer $\mathbf{3}$ has the anchor group on a different position, forcing electron flow to an alternate position, apparently reducing the efficiency of charge injection. The data also suggest that the cyanoacetic acid derived anchor is better than a simple carboxylic acid group in their dual role of charge-withdrawing and anchoring 
Table 2. DSSC Performance Parameters of BODIPY Dyes ${ }^{a}$

\begin{tabular}{ccccc}
\hline dye & $V_{\text {oc }}(\mathrm{V})$ & $J_{\text {sc }}\left(\mathrm{mA} \mathrm{cm}^{-2}\right)$ & $f$ & $\eta(\%)$ \\
\hline $\mathbf{1}$ & 0.80 & 2.27 & 0.37 & 0.68 \\
$\mathbf{2}$ & 0.64 & 1.61 & 0.28 & 0.28 \\
$\mathbf{3}$ & 0.59 & 1.49 & 0.38 & 0.33
\end{tabular}

${ }^{a} V_{\mathrm{oc}}$ is the open-circuit potential, $J_{\mathrm{sc}}$ is the short curcuit current, $f$ is the fill factor, and $\eta$ is the overall efficiency of the cell under standard conditions.

Scheme 1. Synthesis of Photosensitizer 2

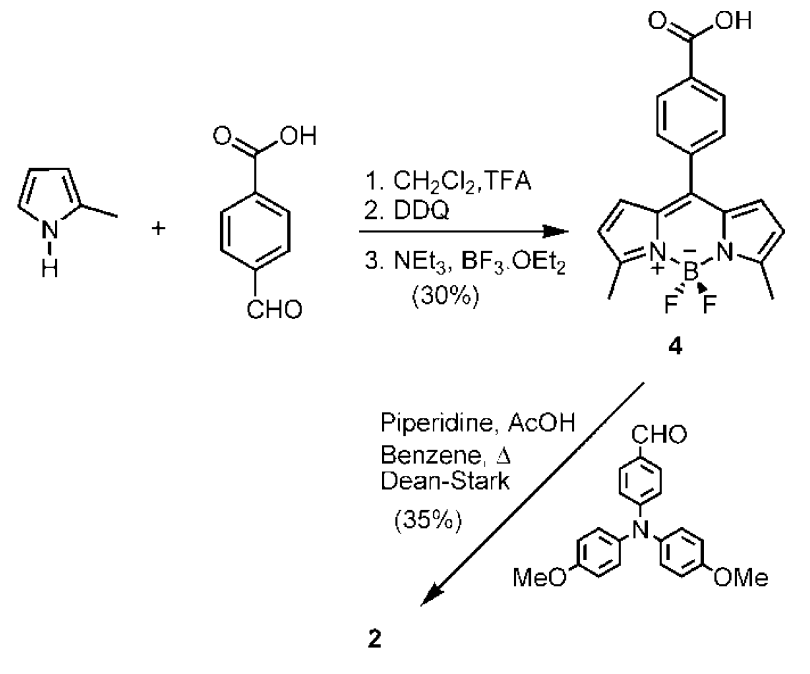

group. As expected, the sensitizers have very low fluorescence emissions due to strong charge transfer characteristics of the diphenylaminophenyl substituent.

What is also remarkable is the near flat response of these sensitizers in the visible wavelengths. Actually, the response is one that could be expected from a black dye.

Table 2 lists some cell parameters for the solid-state DSSCs prepared using these sensitizers. The overall conversion efficiency is highest for the sensitizer $1(\eta=0.68 \%)$, which could be considered a respectable value for an organic dye with a solid-state redox mediator. It appears that solution
Scheme 2. Synthesis of Sensitizer 3

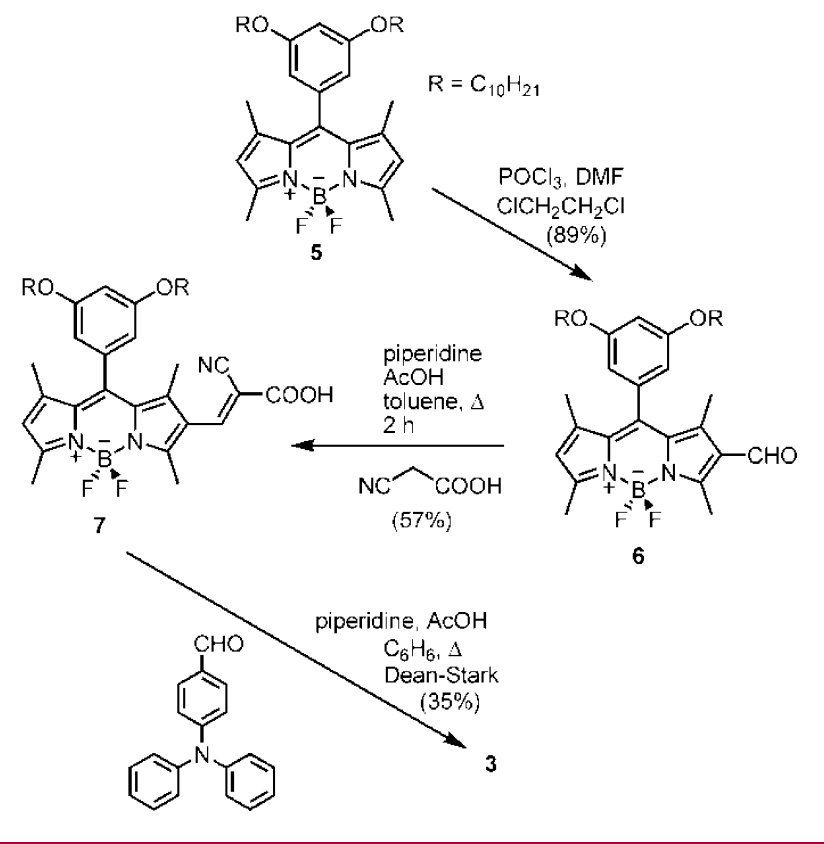

properties only loosely translate into properties on titania. However, Bodipy-based sensitizers still hold significant promise as they can be derivatized as desired and the absorption peaks can be moved along the visible and nearIR region. It is interesting to note that one of the most efficient dyes in terms of monochromatic incident photon to current conversion is indeed a Bodipy dye. It looks like Bodipy dyes, which are known for their bright fluorescence, are likely to find novel applications as photosensitizers. We will continue in fine-tuning the Bodipy structure toward ever more efficient dyes for dye-sensitized solar cells through rational design.

Supporting Information Available: Experimental procedures, structural proofs, and additional spectral data for all new compounds. This material is available free of charge via the Internet at http://pubs.acs.org.

OL1014762 